\title{
An indigenous community-based monitoring system for assessing forest health in New Zealand
}

\author{
P. O'. B. Lyver' ${ }^{1}$ P. Timoti ${ }^{2}$ - C. J. Jones ${ }^{1}$ - S. J. Richardson ${ }^{1}$. \\ B. L. Tahi ${ }^{2} \cdot$ S. Greenhalgh ${ }^{3}$
}

Received: 25 November 2015/Revised: 4 May 2016/Accepted: 12 May 2016/

Published online: 30 May 2016

(C) The Author(s) 2016. This article is published with open access at Springerlink.com

\begin{abstract}
The underlying ethos of 'nature's benefits' contributing to human wellbeing provides a common platform for understanding the function and value of biodiversity for stakeholders. Diverse societal worldviews however create differences in the way cultures relate to and understand the environment. The objective of this study was to identify community-based indicators and metrics used by Māori in New Zealand to monitor forest health and community wellbeing. Eighty semi-directed interviews were conducted with 55 forest users within the Tuawhenua tribal group to identify forest health indicators and associated gradient of metrics to assess each indicator. Indicators were grouped within nine culturally-relevant themes: (1) food procurement (mahinga kai), (2) natural productivity (hua o te whenua), (3) nature of water (āhua o te wai), (4) nature of the land (āhua o te whenua), (5) nature of the forest (āhua o te ngahere), (6) perpetual occupation of land and place (ahikaaroa), (7) spiritual dimension (taha wairua), (8) physical health (taha kikokiko), and (9) mental health (taha hinengaro). Within these themes, indicators and associated metrics were aligned within two monitoring approaches: field survey and interviewbased. Community members ( $\mathrm{n}=35$ individuals) were asked to prioritise field survey indicators using a seven point Likert Scale of importance. A second survey was also conducted with Tuawhenua elders ( $\mathrm{n}=43$ individuals) to determine changes in the frequency of forest use by the community. A decline in the proportion of the community
\end{abstract}

Communicated by Eckehard Brockerhoff, Hervé Jactel and Ian Thompson.

This is part of the special issue on 'Forest biodiversity and ecosystem services'.

Electronic supplementary material The online version of this article (doi:10.1007/s10531-016-1142-6) contains supplementary material, which is available to authorized users.

P. O'. B. Lyver

lyverp@landcareresearch.co.nz

Landcare Research, PO Box 69040, Lincoln 7640, New Zealand

2 Tūhoe Tuawhenua Trust, Private Bag 3001, Ruatāhuna, Via Rotorua, New Zealand

3 Landcare Research, Private Bag 92170, Auckland Mail Centre, Auckland 1142, New Zealand 
venturing into the forest over the last 60 years for activities such as hunting, fishing, camping, and collecting plant resources was reported. This decline in regular forest use suggests a field survey approach would be an effective method for applying communitybased indicators and to gain an understanding of forest health. Forest indicators that are evaluated over a longer timeframe (months, seasons or even years), or those indicators aligned with community wellbeing, would be better evaluated using an interview-based approach. The alignment of some community-based indicators with scientific-based measures would enrich and deepen knowledge about the state of biodiversity, broaden the relevance of monitoring and reporting within indigenous communities, and help to mitigate issues of 'shifting baselines'.

Keywords Community-based indicators · Forest health · Indigenous peoples · Traditional knowledge

\section{Introduction}

Knowledge of the natural environment provides the basis of livelihoods and cultures for many indigenous peoples and local communities (IPLCs). The value that indigenous and local knowledge (ILK) has in guiding assessment, protection and restoration of the environment and biodiversity has also become widely recognised by the scientific community (IPBES 2013). Subsequently international and national initiatives to engage IPLCs and their knowledge systems have become increasingly common over the last three decades (Sobrevila 2008; UNEP 2012; CBD 2015). The challenge for governments, international organisations, multilateral environmental agreements (MEAs), and inter-governmental science-policy platforms however has been establishing culturally appropriate approaches, procedures and participatory mechanisms to facilitate and guide the process of engaging IPLCs and their knowledge (Berkes and Folke 1998; Chapin et al. 2010; Thaman et al. 2013).

The ability of a society to comprehend and respond to changes in the environment relies on a robust system for understanding ecosystem structure and processes and inter-relationships between its physical and biological components. The cultural context of a society defines what information is sought and how that information is collected and interpreted and the type of response implemented (Shiel et al. 2015). The type of knowledge collection and interpretation system (scientific or ILK) can also influence the trust a community has in the process and knowledge, and their willingness to act upon that knowledge (Moller et al. 2009). While issues remain around the rendering of indigenous knowledge when removed from its cultural context (Nadasdy 1999; Ens et al. 2015), remains a desire to find mechanisms to facilitate an "indigenous way of knowing" in response to the current global biodiversity crisis (IPBES 2016).

The monitoring of biodiversity, increasingly with indicators derived by indigenous peoples, offers opportunities for engaging local communities in the effort to protect and restore biodiversity. These community-based indicators can offer evidence for interpreting conditions, changes, and trajectories in the environment, and in some cases causal relationships (Tengö et al. 2014). They also support opportunities for communities to monitor the natural environment in a way that they comprehend, relate to and can interpret (e.g., through a spiritual dimension). The act of monitoring by IPLCs also serves a dual purpose 
as it represents an expression of identity and autonomy and infers rights under environmental stewardship arrangements (Agrawal 1995; Bohensky and Maru 2011). Culturally responsive systems for monitoring the state of biodiversity are therefore being explored in a number of countries (e.g., Jollands and Harmsworth 2007; Danielsen et al. 2014a; Shiel et al. 2015).

Many IPLCs still rely heavily on the available resources in their local areas (e.g., water, food, firewood, and clothing). These actions bring them into direct contact with the biological components of ecosystems and contribute to the richness, composition and integrity of their knowledge at a range of temporal and spatial scales, as well as reinforcing their relationship with the surrounding environment. This enables indigenous and local knowledge systems to be "dynamic bodies of social-ecological knowledge, practice and belief, evolving by adaptive processes, grounded in territory, intergenerational and cultural transmission, about the relationship of living beings (including humans) with one another and with their environment" (Berkes 2012). However, the impacts of colonialization on indigenous cultures in some countries (e.g., Māori in New Zealand) and changes in lifestyles (e.g., loss of land, isolation from lands and resources, cultural assimilation policies, rural-urban migration, introduction of exotic plants and animals) have affected how ILK is acquired, enriched, validated and transferred.

Over their 730 years of settlement in New Zealand (Wilmshurst et al. 2014) Māori developed intimate relationships with, and extensive knowledge systems of, their environment and the rich endemic biological diversity encountered therein. While European colonialization over the last 200 years heavily influenced Māori culture, Māori ILK of the environment persists within communities (Wehi 2009; Stephenson et al. 2014). Subsequently, Māori and government authorities are increasingly seeking to engage this knowledge in defining, monitoring and forming solutions and responses to declines in native biodiversity and habitats within their tribal regions (Tipa and Teirney 2006; Harmsworth and Awatere 2013; Ministry for the Environment and Statistics New Zealand 2015a). In New Zealand, the national biodiversity monitoring and reporting system emphasizes species dominance and occupancy, and is implemented across public conservation land, c. one-third of NZ's land area (New Zealand Government 1987; Lee et al. 2005; MacLeod et al. 2012). This national monitoring and reporting system does not currently include Māori or community-based indicators, although local and central government initiatives are exploring opportunities for their use in other capacities (Ministry for the Environment and Statistics New Zealand 2015b).

The overarching goal of this study, therefore, was to develop a Māori community-based monitoring system that primarily tracks the health of a forest ecosystem but also community well-being. To do this, we worked with the people from the Tūhoe Tuawhenua (herein referred to as Tuawhenua) community of Ruatāhuna, which is located within the Te Urewera region in the North Island of New Zealand. We were conscious that Māori communities recognise different indicators and 'survey' the environment in a different manner to that of scientific monitoring systems, with much of the understanding emerging from their intimate kinship relationship with the forest environment. A community-based monitoring system therefore needs to account for how community members interact with a forest environment, if the frequency and reasons that community members interact with the forest has changed, and the timeframes over which different facets of knowledge are acquired.

Using a series of in-depth interviews with past and present forest users, we documented how the Tuawhenua community interacted with their forest environment, and how members perceived and quantified trends and changes in the landscape and biological resources. We used this information to identify indicators the community felt were relevant 
and informative, and considered how these could be used in a community-based monitoring system to inform tribal decision-making and management of the forest. A secondary aim was to understand changes in the frequency of forest use and visitation by the local people over the past 65 years. A decline in forest use by the community could affect observation rates of certain indicators and the way patterns were interpreted and would therefore need to be taken into account when designing a biodiversity monitoring approach.

\section{Methods}

\section{Background and study location}

New Zealand's highly endemic biota has been greatly modified by human settlement. Many species of birds have gone extinct, either through predation from commensal rats (Rattus spp.) that arrived with people in the thirteenth century or from hunting pressure (Tennyson and Martinson 2006). Local extinctions have continued into the recent past and even common species have declined in abundance over the last century (Lyver et al. 2009). Before human settlement, New Zealand lacked land mammals except for three bat species (Chalinolobus tuberculatus; Mystacina spp.) but the biota is now characterised by introduced rodents, mustelids (e.g., stoat, Mustela ermine), ungulates (e.g., feral pig, Sus scrofa) and marsupials (e.g., Australian brushtail possum, Trichosurus vulpecula; King 1990). Freshwater ecosystems have been transformed by European settlers who introduced trout and salmon (Salmonid spp.) to ecosystems formerly dominated by small galaxiid fish (e.g., Galaxias spp.) and tuna (eels, Anguilla spp.).

The Tuawhenua community is part of the Tūhoe tribe which is located within the heavily forested Te Urewera mountain ranges in the eastern region of the North Island, New Zealand (Fig. 1). Te Urewera is the recognised tribal homeland of Tūhoe. Tūhoe is the seventh largest tribe in NZ with its population numbering 34,890 in 2013 (Statistics New Zealand 2013). Most of the Tūhoe population ( $~ 81 \%)$, including those of Tuawhenua descent, now live outside of this traditional homeland (Nikora et al. 2004), with the remaining population focused around small villages in different parts of the region. The Tuawhenua village of Ruatāhuna consists of approximately 300 people clustered around 10 traditional meeting places (marae) established by eight different, but related sub-tribes within the heart of this region (Morunga and Tahi 2013).

\section{The Tuawhenua forests}

The Tūhoe Tuawhenua Trust is an entity formed in 1987 to administer approximately 8800 hectares of mostly forested lands owned by Tuawhenua sub-tribes. More than $95 \%$ of the Tūhoe Tuawhenua Trust lands are covered with mixed oceanic temperate rain forests. Canopies are dominated by evergreen angiosperms such as tawa (Beilschmiedia tawa, Lauraceae) and tawhero (Weinmannia racemosa, Cunoniaceae) with emergent conifers in the Podocarpaceae (e.g., Prumnopitys spp., Dacrydium cupressinum and Podocarpus spp.). Selective logging between 1956 and 1975 by a private forestry company removed a large proportion of the native conifers, particularly those found on alluvial terraces and accessible toe-slopes. Regeneration and post-logging recovery has been poor and forests are 


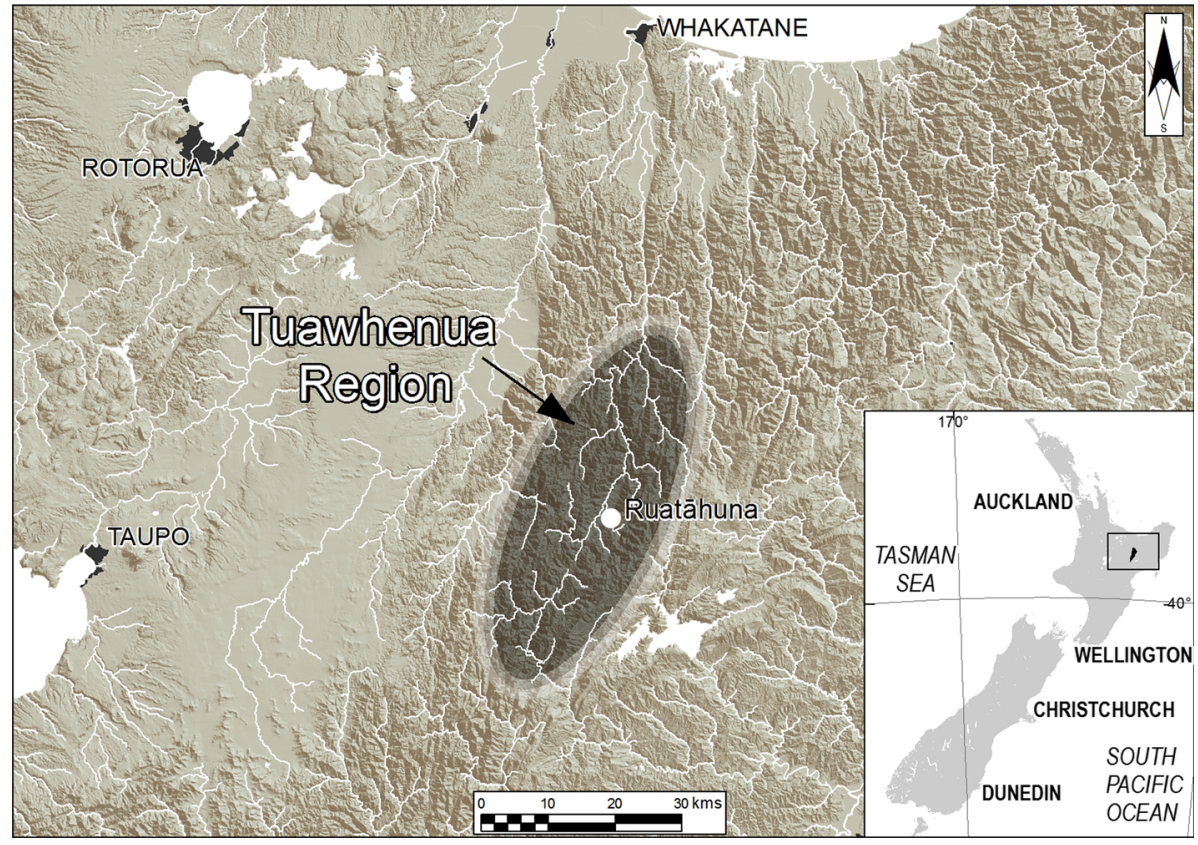

Fig. 1 Location of the Tuawhenua region and community of Ruatāhuna within the Te Urewera mountain range, New Zealand

currently dominated by shade-tolerant angiosperms, particularly tawa (Carswell et al. 2007). The rivers and forests around Ruatāhuna have traditionally provided the community with a valued source of native biota for food, medicine (rongoā), building, clothing, weaving, and carving materials, firewood, and cultural and recreational activities, although some exotic species are now highly valued as sources of protein (e.g., red deer, feral pig) or fur (e.g., Australian brushtail possum).

\section{Knowledge collection process with Tuawhenua}

Three independent rounds of interviews were conducted between 2004 and 2014 and focused on aspects relating to Te Urewera and the Tuawhenua peoples' use and relationships with the forest. The underlying context for the interviews was to record mâtauranga that would contribute to future management of the forest by the tribe. All rounds of interviews offered relevant narrative which allowed researchers to identify and understand community indicators of forest health. All interviewees were originally from Ruatāhuna or had lived in the community for over 35 years. Participants were then selected based on their current or past use of the forest and who possessed knowledge and experiences relating to the forest. In total, we interviewed 55 individuals ( $\mathrm{n}=80$ interviews) in both Māori and English (Table 1). All interviews conducted in Māori were transcribed and translated into English, and verified by local practitioners fluent in the local Tūhoe dialect.

The first round of interviews focused on a cultural keystone species, the kererū (Hemiphaga novaeseelandiae), a fruit pigeon that was highly abundant within Te Urewera forests historically, but has declined significantly over the last century. Kererū are highly 


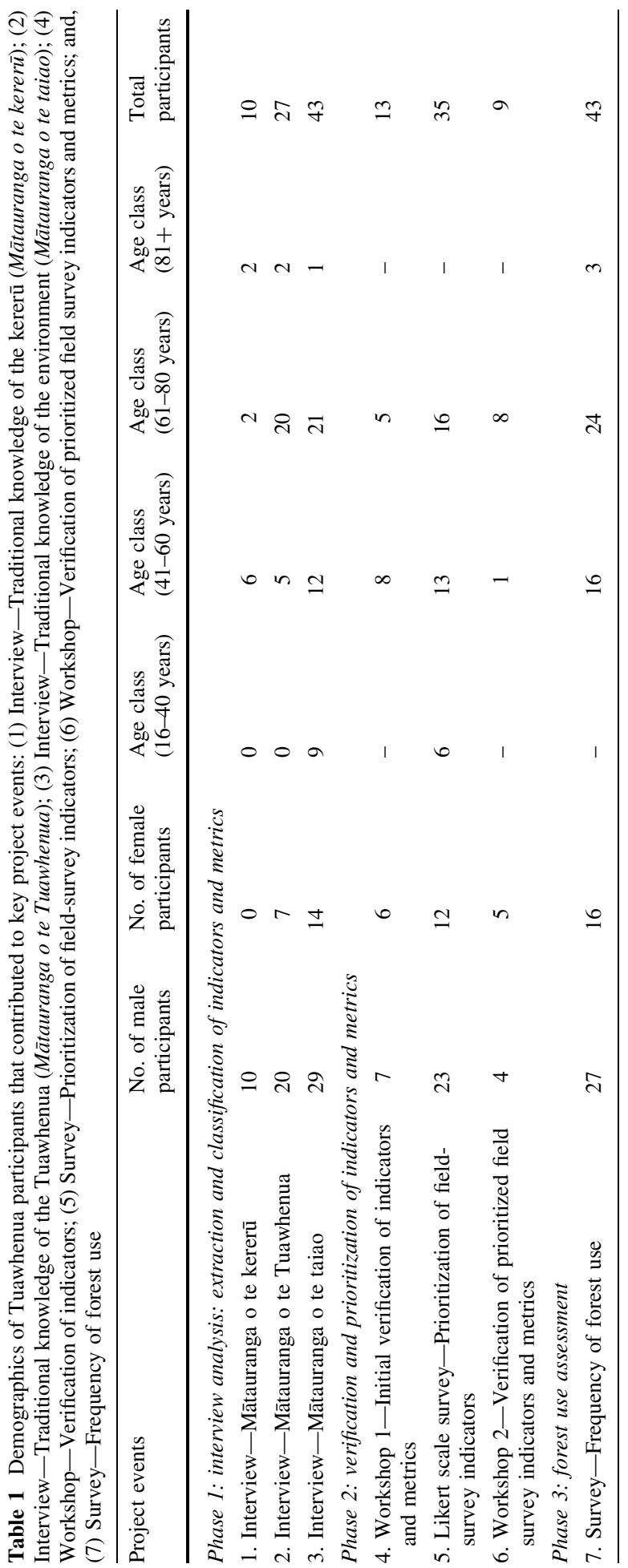


valued by Tuawhenua as a source of food and feathers (Lyver et al. 2008). From a possible participant pool of 20 individuals, identified as having knowledge pertaining to the kererū, we interviewed a total of 10 male elders (Table 1; age range: 50-84 years) about their knowledge of the kererū (Mătauranga o te kererū). Men were primarily the ones that hunted the kererū and therefore held much of the knowledge relating to the customs and practices of the harvest. The interviews were conducted between 2004 and 2007 and ranged from 1.5 to $3 \mathrm{~h}$ in length. They addressed: (1) long-term changes in the kererū population, (2) cultural indicators used to gauge kererū abundance, (3) the direct and indirect impacts of introduced mammals and birds on kererū, (4) the types and seasonal timing of native fruit and leaves that the kererū feed on, (5) the impact of past timber extraction in the region, and (6) observations of changes in climate patterns in the region. More detail on the interview process is available in Lyver et al. (2008) and Lyver et al. (2009).

Our second round of interviews was conducted between 2011 and 2012 and focused on the knowledge held by elders and community members of the flora and fauna within Tuawhenua forests and rivers (Mātauranga ō te Tuawhenua-Traditional knowledge of the Tuawhenua; Table 1; age range 49-79 years). These oral histories largely related to the use of forest resources and movements of community members on the landscape. The primary purpose of these interviews was to inform management of the Tuawhenua forests in a way that reflects Tuawhenua customs and practices and ensures that the forest will provide resources for future generations.

We carried out a third round of interviews (Mātauranga o te taiao-Traditional knowledge of the natural environment) in 2013 and 2014 with Tuawhenua elders and community members who were forest users (Table 1; age range 21-83 years). The interviews addressed Tuawhenua knowledge of: (1) trends and changes in biodiversity, (2) indicators of the state and change of biodiversity, (3) relationships between plants, animals and people, and (4) the aspirations the community members held for their lands and forests. The emphasis for this round of interviews was to resolve how a Māori organisation can develop and implement community-based indicators to assess both the state of their forest and progress towards ecological and livelihood outcomes on trust-administered lands.

\section{Extraction, classification, prioritization and verification of indicators and metrics}

We adopted a five-stage process to extract, classify, verify and prioritize indicators and associated metrics from the transcribed and translated interviews (Table 1):

1. Extraction In the first stage of the process two authors representing both scientific (PL) and Tuawhenua (PT) worldview extracted information from a sub-sample of five interviews to determine preliminary categories under which the indicators could be grouped initially. The purpose of this preliminary extraction process was to allow the researchers to appreciate the range of indicators reported within the interviews and how they were used. The process was also used by the two researchers to introduce some congruency and uniformity in the extraction of indicators. Based on this process we identified seven categories: (1) culture and society, (2) cosmology, (3) exotic species, (4) native species, (5) structure and condition of forest, (6) perturbations and anomalies, and (7) water. The remaining 75 interviews were then analysed by PL and PT to align indicators to each of the categories 
2. Classification The second stage of the process involved the assignment of the extracted indicators into culturally-relevant themes (pae tukutuku) that were relevant to Tuawhenua. Based on the range of indicators reported by interviewees and feedback from the workshop participants, nine culturally-relevant themes were established by PL and PT: (1) food procurement (mahinga kai), (2) natural productivity (hua o te whenua), (3) nature of water (āhua o te wai), (4) nature of the land (āhua o te whenua), (5) nature of the forest (āhua o te ngahere), (6) perpetual occupation of land and place (ahikaaroa), (7) spiritual dimension (taha wairua), (8) physical health (taha kikokiko), and (9) mental health (taha hinengaro). Within each category, each indicator was assigned to one of two monitoring approaches (ngā pae o te mātauranga) according to the manner each would be implemented within a future monitoring system: 'field survey' (ngā pae tata); and 'interview-based' (ngā pae tawhiti) assessments. Gradients of metrics associated with each field survey indicator were also identified from the interview narrative

3. Initial verification In the third stage of the process, we presented the extracted indicators (and associated metrics) to a sub-sample of the original Tuawhenua interviewees in a workshop. The one-day workshop was attended by 13 participants (Table 1; mean age 59 years; age range 39-80 years) and conducted primarily in the Māori language. Narrative from the workshop was audio-taped, translated and transcribed into English afterwards. The feedback was used to verify how indicators were used and aligned to culturally-relevant themes. The process was also used to cross-check the wording or phrases interviewees used to describe the state and condition of indicators (i.e. gradient of metrics)

4. Prioritization Owing to the large number of field survey indicators identified during the extraction phase (Table 2), 35 community members (Table 1; mean age 57 years; age range 26-78 years) were independently surveyed and asked to score the indicators on a seven point Likert Scale of importance. Based on feedback from community members, the 25 top ranking indicators were used to form the basis of a field survey approach

5. Final verification In the final stage of the process, we presented the 25 prioritized field survey indicators and associated gradient of metrics to Tuawhenua elders in a workshop for final verification. The one-day workshop was attended by 9 elders (Table 1; mean age 67 years; age range 59-78 years) and was conducted primarily in Māori, but also partly in English. Adjustments of the wording used to describe the indicators and metrics were made based on the guidance received from elders

\section{Frequency of forest use by Tuawhenua}

To assess the changes in the frequency of forest use by the community we surveyed 43 Tuawhenua elders over the age of 55 years in 2015 (Table 1; mean age 65 years; median age 63 years). We asked elders to estimate the proportion of the community who visited the forest regularly for hunting, fishing or collecting plant materials for food, weaving or medicinal purposes in the recent past (1981-2015) and the distant past (1945-1980). The goal was to ask each individual for their perspective on frequency of forest visits by the community as a whole during these periods-not the frequency of their own personal visits. This was to negate the effect of increasing age on frequency of forest visits by the 
Table 2 Culturally-relevant themes (pae tukutuku), monitoring approaches (ngā pae o te mātauranga) and community-based indicators (tohu) used by Tuawhenua Māori to inform on forest health and condition within the Te Urewera mountain range, North Island, New Zealand. The two monitoring approaches were a field survey approach (ngā pae tata) and interview-based approach (ngā pae tawhiti)

\begin{tabular}{lll}
\hline $\begin{array}{l}\text { Culturally-relevant } \\
\text { themes (Pae }\end{array}$ & Monitoring approach & Indicators (Tohu) of forest health and condition \\
tukutuku) & māā pae o te & \\
\hline
\end{tabular}

$\begin{array}{lc}\begin{array}{l}\text { Procurement of food } \\ \text { (Mahinga kai) }\end{array} & \begin{array}{c}\text { Field survey (Ngā pae } \\ \text { tata) }\end{array}\end{array}$

Interview-based ( $\mathrm{Ngā}$ pae tawhiti)
- Frequency of wildlife sightings

- Native bird flock size (e.g., kererū, kōkō, pihipihi)

- Nocturnal and diurnal native bird calls-noise levels, abundance of calls [e.g., kiwi (Apteryx mantelli), ruru (Ninox novaeseelandiae), kākā, kākāriki (Cyanoramphus spp.), koparapara (Anthornis melanura)]

- Prevalence and densities of possum and deer faecal pellets or feral pig, cow (Bos taurus) and horse (Equus ferus caballus) dung

- Extent and depth of deer, feral pig, cow and horse tracks and pugging of soil

- Prevalence of red deer antler thrashing on trees

- Extent and depth of feral pig rooting

- Intensity of fungi (harore) odour in forest

- Prevalence and density of pikopiko [shoots of the hen and chicken fern (Asplenium bulbiferum)]

- Condition and quality of pikopiko [shoots of the hen and chicken fern (Asplenium bulbiferum)]

- Size of groupings (e.g., raumahehe-native freshwater fish (Galaxias spp.); herd size-red deer)

- Audible bird activities (e.g., wing flapping in canopy; prevalence of guano dropping through canopy; level of forest rustling, sound of twigs and branches breaking)

- Flock density (e.g., kererū per tree; flocks flying overhead shading the sun)

- Timing of flocking (e.g., kererū, pihipihi)

- Prevalence and density of roaring red deer stags

- Prevalence and density of ruatuna (freshwater longfin eel (tuna) holes in the riverbanks)

- Harvest tallies

- Harvest rates of wildlife (e.g., freshwater longfin eel (tuna), birds, feral pig, red deer)

- Distance travelled to harvest wildlife

- Length of harvest season

- Size of hunter groups

- Size of animals (e.g., freshwater longfin eel (tuna), pigs)

- Amount of fat on harvested wildlife (e.g., freshwater longfin eel (tuna), birds, feral pigs, red deer)

- Colour of fat of harvested wildlife (e.g., freshwater longfin eel (tuna), birds, feral pigs)

- Flavour of flesh and/or fat of harvested wildlife (e.g., freshwater longfin eel (tuna), birds, feral pigs)

- Smell of flesh and/or fat of harvested wildlife (e.g., freshwater longfin eel (tuna), birds, feral pigs)

- Texture of flesh (e.g., kererū)

- Prevalence of deer and feral pig beds

- Behavioural characteristics of wildlife 
Table 2 continued

\begin{tabular}{|c|c|c|}
\hline $\begin{array}{l}\text { Culturally-relevant } \\
\text { themes (Pae } \\
\text { tukutuku) }\end{array}$ & $\begin{array}{l}\text { Monitoring approach } \\
\text { (Ngā pae o te } \\
\text { mātauranga) }\end{array}$ & Indicators (Tohu) of forest health and condition \\
\hline \multirow[t]{2}{*}{$\begin{array}{l}\text { Natural productivity } \\
\text { (Hua o te whenua) }\end{array}$} & $\begin{array}{l}\text { Field survey } \\
\text { (Ngā pae tata) }\end{array}$ & $\begin{array}{l}\text { - Fruit abundance and density on trees [e.g., hīnau } \\
\text { (Elaeocarpus dentatus), toromiro (Prumnopitys } \\
\text { ferruginea) } \\
\text { - Fruit abundance and density on ground (e.g., hīnau, } \\
\text { tawa) } \\
\text { - Size of fruit [e.g., tawa, hīnau, kāramuramu } \\
\text { (Coprosma lucida)] } \\
\text { - Flower abundance and density on trees (e.g., intensity } \\
\text { of colour) } \\
\text { - Prevalence of species for carving (whakairo) or tool } \\
\text { making (e.g., tōtara, Podocarpus totara) } \\
\text { - Prevalence of plants for traditional tattooing } \\
\text { (tāmoko) } \\
\text { - Prevalence of plants for weaving (raranga) or use as } \\
\text { garments such as mauku } \\
\text { - Quality of plants for weaving (raranga) or use as } \\
\text { garments such as mauku } \\
\text { - Prevalence and density of medicinal plants (rongoā) } \\
\text { - Visual appearance of medicinal plants (rongoā) }\end{array}$ \\
\hline & $\begin{array}{l}\text { Interview-based } \\
\text { (Ngā pae tawhiti) }\end{array}$ & $\begin{array}{l}\text { - Fruit condition (e.g., intensity of colour; intenseness } \\
\text { of flavour) } \\
\text { - Strength of odour associated with flower blooms } \\
\text { - Prevalence of feather use [e.g., kererū feathers for } \\
\text { cloaks (korowai), mattresses and pillows] } \\
\text { - Effectiveness and potency of medicinal plants } \\
\text { (rongoā) } \\
\text { - Feral bee (Apis mellifera) hive prevalence and } \\
\text { density } \\
\text { - Trap catch rates of possums }\end{array}$ \\
\hline \multirow[t]{2}{*}{$\begin{array}{l}\text { Nature of water } \\
\text { (Āhua o te wai) }\end{array}$} & $\begin{array}{l}\text { Field survey (Ngā pae } \\
\text { tata) }\end{array}$ & $\begin{array}{l}\text { - Quality of water in rivers or streams (e.g., taste of } \\
\text { water) } \\
\text { - Aesthetics of river or streams (e.g., water clarity) } \\
\text { - Prevalence of weed and algae in rivers or streams } \\
\text { - Smell of rivers or streams } \\
\text { - Language or sound of the rivers or streams } \\
\text { - Presence of freshwater invertebrates [e.g., freshwater } \\
\text { crayfish (koura, Paranephrops planifrons) and } \\
\text { vertebrates [e.g., native freshwater fish (raumahehe), } \\
\text { native frog (pepeketua/poroka, Leiopelma } \\
\text { hochstetteri)] }\end{array}$ \\
\hline & $\begin{array}{l}\text { Interview-based (Ngā } \\
\text { pae tawhiti) }\end{array}$ & $\begin{array}{l}\text { - Presence, abundance and water volume of springs } \\
\text { and streams (e.g., river flows; height of water table; } \\
\text { presence of springs/creeks) } \\
\text { - Number of flood events } \\
\text { - Intensity and scale of flood events }\end{array}$ \\
\hline
\end{tabular}


Table 2 continued

\begin{tabular}{|c|c|c|}
\hline $\begin{array}{l}\text { Culturally-relevant themes } \\
\text { (Pae tukutuku) }\end{array}$ & $\begin{array}{l}\text { Monitoring approach } \\
\text { (Ngā pae o te } \\
\text { mātauranga) }\end{array}$ & Indicators (Tohu) of forest health and condition \\
\hline \multirow[t]{2}{*}{$\begin{array}{l}\text { Nature of land (Āhua o te } \\
\text { whenua) }\end{array}$} & $\begin{array}{l}\text { Field survey (Ngā pae } \\
\text { tata) }\end{array}$ & $\begin{array}{l}\text { - Dryness of soil } \\
\text { - Extent of tree cover in a riverbed or amount of } \\
\text { shading over a river or stream }\end{array}$ \\
\hline & $\begin{array}{l}\text { Interview-based (Ngā } \\
\text { pae tawhiti) }\end{array}$ & $\begin{array}{l}\text { - Abundance of land-slides ('slips') } \\
\text { - Size and depth of land-slides ('slips') } \\
\text { - Air temperature } \\
\text { - Intensity and extent of snow events } \\
\text { - Intensity and extent of flood and storm events } \\
\text { - Intensity and persistence of wind } \\
\text { - Timing of frosts } \\
\text { - Changes in distribution of vegetation and } \\
\text { wildlife }\end{array}$ \\
\hline \multirow[t]{2}{*}{$\begin{array}{l}\text { Nature of the forest (Āhua o } \\
\text { te ngahere) }\end{array}$} & $\begin{array}{l}\text { Field survey (Ngā pae } \\
\text { tata) }\end{array}$ & $\begin{array}{l}\text { - Shape of forest canopy } \\
\text { - Seedling densities } \\
\text { - Sapling densities } \\
\text { - Extent and occurrence of vegetation browse, } \\
\text { damage or trampling } \\
\text { - Forest floor cover } \\
\text { - Visibility of tree trunks } \\
\text { - Line of sight and openness within forest } \\
\text { - Line of travel within forest } \\
\text { - Windiness within forest } \\
\text { - Prevalence of layering in canopy } \\
\text { - Cleanliness of forest (e.g., prevalence of } \\
\text { windfall) } \\
\text { - Size and openness of historic clearings } \\
\text { - Colour of forest } \\
\text { - Language or sound of forest } \\
\text { - Levels of canopy shading within forest } \\
\text { - Aesthetics or beauty of forest } \\
\text { - Flock size of introduced birds (e.g., Common } \\
\text { - Level of audible sound associated with } \\
\text { introduced species' (e.g., common wasp, feral } \\
\text { bee, birds, possums) } \\
\text { - Prevalence of possum sign (e.g., pellets, runs or } \\
\text { paths, bite marks and scratchings in tree bark) }\end{array}$ \\
\hline & $\begin{array}{l}\text { Interview-based (Ngā } \\
\text { pae tawhiti) }\end{array}$ & $\begin{array}{l}\text { - Dryness of foliage } \\
\text { - Sightings of new species (changes in } \\
\text { distribution) } \\
\text { - Level of audible sound associated with } \\
\text { introduced species' (e.g., possum mating calls) } \\
\text { - Timing of flower blooms } \\
\text { - Spatial variation in flower blooms } \\
\text { - Timing of fruiting }\end{array}$ \\
\hline $\begin{array}{l}\text { Long burning fires of } \\
\text { occupation of land and } \\
\text { place (Ahikaaroa) }\end{array}$ & $\begin{array}{l}\text { Interview-based (Ngā } \\
\text { pae tawhiti) }\end{array}$ & $\begin{array}{l}\text { - Frequency of forest use and visitation } \\
\text { - Collectiveness and use of prayer/incantations } \\
\text { (karakia), waiata (songs), and also songs sung in } \\
\text { traditional mode (mōteatea) } \\
\text { - Strength of linkages to land and food }\end{array}$ \\
\hline
\end{tabular}


Table 2 continued

\begin{tabular}{|c|c|c|}
\hline $\begin{array}{l}\text { Culturally-relevant } \\
\text { themes (Pae } \\
\text { tukutuku) }\end{array}$ & $\begin{array}{l}\text { Monitoring approach } \\
\text { (Ngā pae o te } \\
\text { mātauranga) }\end{array}$ & Indicators (Tohu) of forest health and condition \\
\hline $\begin{array}{l}\text { Spiritual dimension } \\
\text { (Taha wairua) }\end{array}$ & $\begin{array}{l}\text { Field survey (Ngā pae } \\
\text { tata) } \\
\text { Interview-based (Ngā } \\
\quad \text { pae tawhiti) }\end{array}$ & $\begin{array}{l}\text { - Presence and strength of life force (mauri) in a forest } \\
\text { - Presence and strength of energy flow (ia) in a forest } \\
\text { - Strength of inspiration, essential force or awe (ihi) } \\
\text { felt within a forest } \\
\text { - Strength of loneliness (mokemoke) felt within a } \\
\text { forest } \\
\text { - Presence or encounter rates with supernatural forest } \\
\text { dwelling beings (e.g., tūrehu, patupaiarehe) } \\
\text { - Presence of environmental guardians (e.g., taniwha) } \\
\text { - Strength of sacredness surrounding species (e.g., } \\
\text { kererū, ruru) } \\
\text { - Presence and strength of sacredness (tapu) }\end{array}$ \\
\hline $\begin{array}{l}\text { Physical health (Taha } \\
\text { kikokiko) }\end{array}$ & $\begin{array}{l}\text { Interview-based (Ngā } \\
\text { pae tawhiti) }\end{array}$ & $\begin{array}{l}\text { - General levels of health of people in community (e.g., } \\
\text { nutrition; food sources; obesity; dental wellness) } \\
\text { - Frequency of locally grown or hunted food in diet } \\
\text { (e.g., cropping) }\end{array}$ \\
\hline $\begin{array}{l}\text { Mental health (Taha } \\
\text { hinengaro) }\end{array}$ & $\begin{array}{l}\text { Interview-based (Ngā } \\
\text { pae tawhiti) }\end{array}$ & $\begin{array}{l}\text { - Commitment to community caring and togetherness } \\
\text { (matemateone) } \\
\text { - Awareness and commitment to the spiritual } \\
\text { dimensions (wairua) } \\
\text { - Quantity and rate of traditional knowledge } \\
\text { (mātauranga) and wisdom (māramatanga) transfer } \\
\text { within community } \\
\text { - Knowledge of and adherence to customary protocols, } \\
\text { rules and practices (tikanga) }\end{array}$ \\
\hline
\end{tabular}

elders themselves, and also because we wanted impressions related to the whole community, not just individuals who were known to be forest users. Each interviewee was asked the following questions:

1. Did more people in the community go into the forest to hunt, fish, camp or collect plant and tree products for food, firewood, medicinal purposes, weaving or carving materials in the period between 1945 and 1980 than the period between 1981 and 2015 ?

2. What percentage $(0,25,50,75,100 \%)$ of the community do you think used the forest regularly to hunt, fish, camp or collect plant and tree products for food, firewood, medicinal purposes, weaving or carving materials in the period between 1945 and 1980 ?

3. What percentage $(0,25,50,75,100 \%)$ of the community do you think used the forest regularly to hunt, fish, camp or collect plant and tree products for food, firewood, medicinal purposes, weaving or carving materials in the period between 1981 and 2015 ?

Proportions were estimated as ordinal values $(1=0-25 \% ; 2=25-50 \%$; $3=50-75 \% ; 4=75 \%+$ ) and modelled using a cumulative link mixed effects model (clmm), appropriate for ordinal or rank data, implemented with the function 'clmm' in the R library 'ordinal' (Christensen 2015). To formally test for differences in perceived proportions, we fitted two models: one modelled the ordinal proportion values as a function of 
the time period (recent vs distant past) and the other was an intercept-only model (i.e. fitting an overall mean to the data without any predictor terms). These two models were compared using a likelihood ratio test to determine whether the model using time period explained significant variation in the 'forest use' proportions. In both models, we specified a random effect to account for the non-independence of the two observations by each elder.

\section{Results}

\section{Indicators related to resource availability}

Of the nine culturally-relevant themes identified, the indicators within the food procurement category were primarily focused on the harvest or collection of native and exotic animals (e.g., native birds such as kererū; pihipihi, Zosterops lateralis; longfin eel, A. dieffenbachia; feral pig; rusa deer, Rusa timorensis; red deer), native and exotic plants (e.g., puha/sow thistle, Sonchus oleraceus, S. asper; watercress, Nasturtium officinale; tī kouka/cabbage tree, Cordyline australis; pikopiko/hen and chicken fern shoots, Asplenium bulbiferum) and fungi (e.g., harore, Armillaria novaezelandiae).

Food harvesting is our world. Going to the bush to hunt for pigs, eeling at night or during the day, and other methods of gathering wild foods is a great passion of mine. There wasn't one task that was greater than the other because each season produced different foods accordingly. Therefore, everything was on time for harvest like chasing pigs, deer and activities like eeling. The seasons didn't overlap with each other. That's how I see it. (Te Mahururangi Te Kaawa 2014; translated from Māori; Online Resource 1-Transcript 1).

Field survey food procurement indicators included direct observations of the abundance of particular species (e.g., bird abundance, flock size) or 'sign' left by the species (e.g., browse damage, tracks, faecal pellets; Table 2, food procurement-field survey). The interview-based indicators were typically participants' impressions of resource and/or forest condition formed over multiple trips or hunting expeditions.

Our forest has changed significantly over time. In the past there weren't many animals in our forest, there were pigs and deer but that was it. I'm talking about the years beyond $1945 \ldots$ There were a lot of pigs at that time; however, those pigs didn't dig up the land and forest like today's pigs. So the question arises,... what has changed? In those days the fruit of the trees [dropping to the forest floor] were plentiful and the pigs didn't need to dig for their sustenance due to the abundance of fruit and the lack of competition. Then came the introduction of other animals that devoured the fruits of the land and hence the pigs started to dig underground for their food source. The deer went through the same process, when they first arrived there was a bounty of small trees and other food sources now those have gone. The deer today have resorted to eating the bark of the smaller trees because those trees have grown bigger and the outcome is that those trees will die. Those are some of the changes that have occurred over time (Tahae Doherty 2014; translated from Māori; Online Resource 1-Transcript 2).

Interviewees often referred to the condition or quality of resources, in particular the fat content of birds, eels, and pigs. The amount, colour, smell or texture of the fat or flesh of 
animal were commonly used to indicate the state of other resources on which the animals may have been feeding (e.g., abundant and white coloured pig fat indicated that there had been a good fruiting of the hinnau, Elaeocarpus dentatus). As many of the native bird species have undergone substantial declines over the last 50 years, some indicators like kererū abundance measured by the degree to which flocks shaded the sun or the levels of noise associated with kererū "rustling", "breaking branches" or "excreting guano" through the canopy were considered less relevant in the current environment (Table 2, food procurement-interview-based).

It isn't like the old days when the beautiful thunderous sounds of the birds were consistently heard. It may well be that I have lost the skills of listening to the sounds of our forest? Nevertheless, I have noticed the great declines in our birds from the times when we grew up. There was always a consistent uproar of birds singing in our forests. When we journeyed into the forest with our father he would dismount to give his horse a rest and, he would tell us stories pertaining to the different species of birds and trees in our environment. I remember one particular time he says "Listen! Listen to what is going on in the forest. Can you hear the birds?" He would add, "You aren't listening to the language of the trees and the birds." I couldn't make any sense of it at the time and I would think to myself, now how would I know what the trees are saying? The language of the trees can be heard if you listen carefully. In those days I thought it was only the rustling of the leaves while the wind blew. But I do believe that the forest isn't as healthy as it used to be (Menu Ripia 2014; translated from Māori; Online Resource 1-Transcript 3).

For the interviewees, natural productivity was very much about monitoring and understanding annual abundance and condition of the forest system, although some indicators were derived from observations made over multiple years. A number of indicators represented the abundance and potency of resources for uses other than food, such as fronds of the mauku (hen and chicken fern, Asplenium bulbiferum) used to make clothing and medicinal plants (rongoā) (Table 2, natural productivity-field survey).

The places I travelled in the past to pick pikopiko [shoots of the hen and chicken fern], the mauku grew in abundance all over the place. That was 20 years ago. Every year I would return to those particular areas to pick pikopiko while I was living in Te Waiti and in the last couple of years I have noticed the mauku have diminished quite significantly. Waiongaonga was a place I frequented to pick pikopiko and they grew beautifully up there. Many years later I went back and I was shocked to see that there were no more mauku growing there. I thought to myself, the mauku was growing here in this very spot! Now they're gone (Menu Ripia 2014; translated from Māori; Online Resource 1-Transcript 4).

Some indicators were highly seasonal so while a field survey approach to monitoring could be used, a survey would need to be undertaken at an appropriate time of year (e.g., spring-flower abundance on trees; intensity of odours). Overlap between indicators in food procurement and natural productivity themes and also between field survey and interview-based monitoring platforms was also recognised (e.g., fruit abundance and density on trees or ground).

In our time boy, the forest was lush and beautiful. There was an abundance of trees growing in the forest. Now, there are places that I have gone to and couldn't find many tawa berries at all. They were a main part of our food source. Harvesting was 
from the end of December to February. There was a set time when they fall off the branches. Parekaeaea was a place where the tawa grew in abundance and they were always loaded with tawa berries (Peho Tamiana 2014; translated from Māori; Online Resource 1-Transcript 5).

\section{Indicators related to the characteristics of water, land and forest}

Indicators within the three culturally-relevant themes: the nature of water, the nature of land and, the nature of forest were used by interviewees to define the character and qualities (āhua) of those landscape components. Interviewees often used assemblages of physical and biological indicators to form their impressions about the ahua of these domains. These indicators were based on observations interviewees made while moving on the landscape, rather than carrying out any specific activity. They were often related to the ease of travelling (e.g., line of sight and travel through the forest, cleanliness of forest) or direct observations of forest attributes (e.g., size, colour, and shape of canopy-Table 2, nature of the forest-field survey). Although the indicators were tangible and comparable (e.g., windiness in forest), they were often used to form an intangible 'feeling' about a place. Declines in culturally significant native species (e.g., kererū; kōkō, Prosthemadera novaeseelandiae; kākā, Nestor meridionalis) or arrival or abundance of introduced species (e.g., bluegum, Eucalyptus saligna; common wasp, Vespula vulgaris) were often said to change the āhua or the nature of a place.

One other matter that I felt sad about was when they planted Ruatāhuna lands with pines and bluegum. If you have a good look at the bluegum species, they're terrible trees because they suck the water out of the ground. The areas with free flowing water have since dried up because those trees have sucked them up. That is my answer to your question regarding the changes of our feelings towards the bush (Ripia Ripia 2014; translated from Māori; Online Resource 1-Transcript 6).

The signs that indicate that the forest is thriving can be found in the presence and the behavioural patterns of insects, birds and animals that reside in the forest. The majority of our indigenous species like the insects, fish, and native birds have diminished; therefore, I think those are signs to show whether the forest is flourishing or diminishing. At present, introduced species from other countries have been brought into our environments and they include trees, animals, birds and insects. So, the forest environment of Tāne [God of the forest realm] is not like the times of our forefathers. The laws that govern have been enforced upon us and the lands have been cleared to cater to housing, farming purposes, to grow European trees and to live the western lifestyle. Ah well, how can our native trees survive this onslaught? (Te Rongonui Tahi 2014; translated from Māori; Online Resource 1-Transcript 7).

\section{Indicators related to the human state}

The final four culturally-relevant themes identified, perpetual occupation of land and place, spiritual dimension, physical health, and mental health were aligned mostly to a long-term interview-based monitoring method as they relied heavily on an intangible perception or sentiment about the state of the forest and/or community (e.g., feeling of awe or force (ihi) or flow of energy (ia) within the forest; sacredness (tapu); Table 2). Tuawhenua interviewees commonly referred to a 'sixth sense' related to the 'feeling' that a place gave an 
individual. These attributes were often, but not always, informed by the tangible indicators. Perceptions or impressions were often built up over long timeframes and draw on a range of different indicators. They are therefore not conducive to a field survey approach. It was acknowledged, however, that impressions relating to the spiritual context (wairua) of a particular location could be formed through single visit to the site (Table 2, taha wairuafield survey).

It was common for interviewees to recount experiencing a supernatural presence or forest-dwelling beings known as tūrehu or patupaiarehe (Table 2, spiritual dimensioninterview-based). These elements influenced how individuals prepared for and conducted themselves while in the forest. Preparations and precautions such as prayer or incantation (karakia), not sleeping on tracks, moving quietly with purpose on the landscape and avoiding specific locations were taken to minimise encounters with these supernatural elements. Encounters were mostly experienced as voices and were to be respected, but not engaged with. Nearly all the interviewees reported experiences with such manifestations while in the forest, although the frequency of encounters had declined in more recent times.

All the old people safeguarded their children and grandchildren whilst they were in the bush. When they went to the forest they normally went with others and did not yell or impart any bad words. That was forbidden. You didn't just play around. The elders cautioned us by saying "Be careful, you aren't the only ones in the bush. There are others there too". We would wonder who else would be in the bush when it was only us there. It wasn't until we were older that they told us about the supernatural forest dwelling beings. They were also in the bush (Hariata Haumate 2014; translated from Māori; Online Resource 1-Transcript 8).

The interviewees relied extensively on the forest for spiritual enrichment, cognitive development, reflection, recreation and physical health, and aesthetic experiences. Interviewees often referred to the forest and lands being linked integrally to their identity, knowledge-belief systems and well-being. This intimate relationship and sense of belonging was reflected in the narrative by one elder:

Let's just say, we have been raised with this thought, 'I am the forest, and the forest is me.' For myself because I was raised in Ruatoki, my umbilical cord (pito) is what connects and empowers me to my land. If I don't have a connection to my land, I am but a puppet with no standing place or homeland. That is what connects me to my land, the place I stand on (Tangiora Tawhara 2014; translated from Māori; Online Resource 1-Transcript 9).

Interviewees saw themselves and the community very much as part of the forest ecosystem, reflecting its traits, health and well-being. Without the people out on the land, the forest was described as becoming "lonely" (Table 2). This was a feeling that a number of interviewees commonly associated with. The subtle erosion around perception of community spirit and caring (matemateone) over the last two to three decades was also linked to this declining use of the land and its native species and resources.

We need to consider our affections and relationships for each other as a community to help strengthen us going forward. In my opinion these concepts [matemateone] have declined or ceased to exist in Ruatāhuna, as if we are strangers in our landscape. That is what I have experienced since my return. We have distanced ourselves from this principle. However difficult, this could still be re-established as it was with our old people. The question is who? Who can reconnect our bonds like that of our 
forefathers? (Hariata Haumate 2014; translated from Māori; Online Resource 1Transcript 10).

\section{Identification of priority field survey indicators}

Using the Likert scale scoring system, 25 priority indicators were used to form the basis of a field survey approach to monitor forest health (Table 3). Indicators and their associated gradient of metrics were grouped within culturally-relevant themes: (1) procurement of food; (2) natural productivity; (3) nature of water; (4) nature of the forest; and (5) spiritual dimension (Table 3).

\section{Frequency of forest use by Tuawhenua}

There was a clear decline in the proportion of the community using the forest between the distant past (1945-80) and the recent past (1981-2015; comparison of intercept-only and fitted models, likelihood ratio test $=119.4$, df $=1.5, P<0.001$; Fig. 2). In the distant past all but one of the elders estimated that at least $50 \%$ of the community visited the forest regularly. None of the elders considered that $50 \%$ or more of the community visited the forest in the recent past (Fig. 2). As one elder in the workshop recounted:

You know this is my own personal observation that a lot of our stuff we spoke about today, for most of us we took our children when they were young into the bush. We taught them that information and we took them to those places to those rivers. You name it. But now that interest just isn't there anymore. Other things are taking priority. I think for a lot of our younger ones because a lot of things are happening now and having families of their own out of the valley. They go out but not into the bush. I have seen children here go up and down this river every weekend, but they don't go there anymore (Te Mahururangi Te Kaawa 2014; spoken in English).

\section{Discussion}

Our comprehensive series of interviews revealed nine culturally-relevant themes to a potential indigenous community-based forest monitoring system in New Zealand. This approach included indicators that overlap with currently implemented national biodiversity measures (e.g., seed fall by dominant forest species; the abundance of ungulate pellets; the abundance of birds) but, importantly, the approach also emphasised the use of biota, a strong interdependence of people and the environment, and a spiritual component. We discuss the challenges confronting indigenous communities in monitoring their environments and consider the value of two different approaches. We also explore the value of widening the current science-based biodiversity monitoring system to support contributions from IPLCs.

\section{An indigenous process for understanding forest and community integrity and health}

Indicators reported in this study provided information on the health of the forest and the condition of the human-biodiversity relationship. Many indicators reported by Tuawhenua people were linked closely to the provisioning capacity of the forest or 'nature's ability to 
Table 3 Culturally-relevant themes (pae tukutuku), indicators (ngā pae tata) and associated metrics contained with a potential field survey approach to monitoring forest health and condition in New Zealand

\begin{tabular}{|c|c|c|}
\hline $\begin{array}{l}\text { Culturally-relevant } \\
\text { themes (Pae tukutuku) }\end{array}$ & Indicators (Ngā pae tata) & Metrics for assessing indicators \\
\hline \multirow[t]{4}{*}{$\begin{array}{l}\text { Procurement of food } \\
\text { (Mahinga kai) }\end{array}$} & $\begin{array}{l}\text { The abundance of native birds in } \\
\text { forest (visual observations) }\end{array}$ & $\begin{array}{l}\text { 1. Full of birds/a lot } \\
\text { 2. Heaps } \\
\text { 3. Quite a few/quite a lot } \\
\text { 4. Not that great/very few } \\
\text { 5. Nothing (Kore)/diminished } \\
\text { 6. Absolutely nothing (Tino kore nei) } \\
\text { 7. Unknown }\end{array}$ \\
\hline & $\begin{array}{l}\text { The abundance of native bird in } \\
\text { forest (sound of birds) }\end{array}$ & $\begin{array}{l}\text { 1. Thunderous (Haruru)/deafening/great } \\
\text { noise-cannot hear yourself speak } \\
\text { 2. Loud and noisy, but less intense } \\
\text { 3. Noise faded/not that great } \\
\text { 4. Silent/muted } \\
\text { 5. Dead silent } \\
\text { 6. Unknown }\end{array}$ \\
\hline & $\begin{array}{l}\text { The amount of possum and deer } \\
\text { pellets or pig, cow or horse dung }\end{array}$ & $\begin{array}{l}\text { 1. Everywhere/carpet } \\
\text { 2. Heaps } \\
\text { 3. Quite a bit/some } \\
\text { 4. Hardly any (Kare i rahi)/not much } \\
\text { 5. Nothing (Kore)/diminished } \\
\text { 6. Absolutely nothing (Tino kore nei) } \\
\text { 7. Unknown }\end{array}$ \\
\hline & The condition and size of tawa fruit & $\begin{array}{l}\text { 1. Large/plump/sweet } \\
\text { 2. Pretty good size/juicy } \\
\text { 3. Mediocre/some juice/mildly sweet } \\
\text { 4. Small/dry/bitter } \\
\text { 5. Unknown } \\
\text { 6. Not relevant }\end{array}$ \\
\hline \multirow[t]{2}{*}{$\begin{array}{l}\text { Natural productivity } \\
\text { (Hua o te whenua) }\end{array}$} & $\begin{array}{l}\text { The extent of flowering in the forest } \\
\text { canopy }\end{array}$ & $\begin{array}{l}\text { 1. Heavy flowering/intense colour of } \\
\text { blooms/powerful strong fragrance or } \\
\text { scent } \\
\text { 2. Lots of flowering/less intense colour of } \\
\text { blooms/some fragrance or scent } \\
\text { 3. Sparse flowering/faded colour of } \\
\text { blooms/little fragrance or scent } \\
\text { 4. No flowers/no colour/no fragrance or } \\
\text { scent } \\
\text { 5. Unknown } \\
\text { 6. Not relevant }\end{array}$ \\
\hline & $\begin{array}{l}\text { The abundance of fruit on the trees } \\
\text { in the forest }\end{array}$ & $\begin{array}{l}\text { 1. Over-loaded (Matomato)/heavily laden } \\
\text { (Makuru) } \\
\text { 2. Plentiful (Manomano)/loaded/heaps } \\
\text { 3. Some/quite a bit } \\
\text { 4. Not a lot/poor fruiting/bugger all } \\
\text { 5. Nothing (Kore)/diminished } \\
\text { 6. Absolutely nothing (Tino kore nei) } \\
\text { 7. Unknown } \\
\text { 8. Not relevant }\end{array}$ \\
\hline
\end{tabular}


Table 3 continued

\begin{tabular}{lll}
\hline $\begin{array}{l}\text { Culturally-relevant } \\
\text { themes (Pae }\end{array}$ & Indicators (Ngā pae tata) Metrics for assessing indicators
\end{tabular}
tukutuku)

Nature of water

(Āhua o te wai)
The abundance of medicinal plant (rongoā) in the forest

The abundance of hen and chicken fern plants (mauku) in the forest
1. Over-loaded (Matomato)/everywhere
(Makuru)

2. Plentiful (Manomano)/heaps

3. Quite a bit/quite a lot

4. Few plants/scattered plants

5. Nothing (Kore)/diminished

6. Absolutely nothing (Tino kore nei)

7. Unknown

1. A Lot (Matomato)/Makuru (everywhere)/countless plants

2. Plentiful (Manomano)/heaps

3. Pockets of mauku

4. Sparse and scattered

5. Gone/Nothing (Kore)/not there

6. Absolutely nothing (Tino kore nei)

7. Unknown

8. Not relevant/wrong habitat for mauku

The condition and quality of hen and chicken fern fronds (mauku)

1. Long and luxurious/good length and colour

2. Short and sparse

3. Short and withered

4. Unknown

5. Not relevant

The abundance of tawa fruit on the forest floor

1. Ground very slippery/a carpet of fruit on the ground

2. Ground slightly slippery/heaps of fruit on the ground

3. Ground not slippery/some fruit on the ground

4. Nothing (Kore)/scattered fruit on ground/fruit is scarce on the ground

5. Absolutely nothing (Tino kore nei)

6. Unknown

7. Not relevant

1. Beautiful/free of weed or algae/no sediment disturbed when rock dislodged

2. Appealing/some weed or algae/some sediment disturbed when rocks dislodged

3. Not as beautiful/quite a bit of weed or algae/a lot of sediment disturbed when rock dislodged

4. Offensive or ugly (Anuanu)/a lot of weed/ weed or algae thick and slimy on rocks/muddy looking

5. Unknown

6. Not relevant

The quality of water in the river (in a normal flow)
1. Beautiful/crystal clear/clean

2. Still clear/some suspended sediment/not bad

3. Murky/cloudy

4. Dirty/muddy

5. Unknown

6. Not relevant 
Table 3 continued

Culturally-relevant $\quad$ Indicators (Ngā pae tata) Metrics for assessing indicators
themes (Pae
tukutuku)

\begin{tabular}{|c|c|c|}
\hline & $\begin{array}{l}\text { The language or sound of the } \\
\text { river }\end{array}$ & $\begin{array}{l}\text { 1. Crisp clear sound of water flowing/sharp 'clack' } \\
\text { of rock hitting rock/ } \\
\text { 2. Sound of water flowing muffled/sand and silt } \\
\text { moving through water/dull 'thud' of rock hitting } \\
\text { rock } \\
\text { 3. River still and stagnant/river noiseless/river muted } \\
\text { over rocks } \\
\text { 4. Unknown }\end{array}$ \\
\hline & $\begin{array}{l}\text { The structure and vegetation } \\
\text { canopy cover of the } \\
\text { riverbed }\end{array}$ & $\begin{array}{l}\text { 1. Trees growing to edge of river right along } \\
\text { channel/stable river channel/shaded river channel } \\
\text { 2. Some trees growing to edge of river but with } \\
\text { widening river bank in places/partially shaded } \\
\text { river channel } \\
\text { 3. No trees growing to edge of river/wide open } \\
\text { gravel river flats/unshaded river channel } \\
\text { 4. Unknown } \\
\text { 5. Not relevant }\end{array}$ \\
\hline \multirow[t]{5}{*}{$\begin{array}{l}\text { Nature of the forest } \\
\text { (Āhua o te } \\
\text { ngahere) }\end{array}$} & $\begin{array}{l}\text { Appearance, beauty, health } \\
\text { and condition of the forest }\end{array}$ & $\begin{array}{l}\text { 1. Beautiful/lush/pristine/thriving/flourishing/whole } \\
\text { 2. Beautiful but rereke (changed)/patchy/ragged/ } \\
\text { scruffy } \\
\text { 3. Barren/bereft/broken/diminished/lonely/withered } \\
\text { 4. Dead } \\
\text { 5. Unknown }\end{array}$ \\
\hline & $\begin{array}{l}\text { The shape and layering of } \\
\text { emergent forest canopy }\end{array}$ & $\begin{array}{l}\text { 1. Beautiful/full canopy } \\
\text { 2. Canopy uneven/canopy patchy } \\
\text { 3. Prolific gaps in canopy/canopy broken and dead } \\
\text { 4. Unknown }\end{array}$ \\
\hline & $\begin{array}{l}\text { The colour of the forest } \\
\text { canopy }\end{array}$ & $\begin{array}{l}\text { 1. Glossy dark green } \\
\text { 2. Olive green with patches of dark green } \\
\text { 3. Olive green with shades of lighter greens and } \\
\text { yellow } \\
\text { 4. Grey and brown } \\
\text { 5. Brown and dry } \\
\text { 6. Unknown }\end{array}$ \\
\hline & $\begin{array}{l}\text { The language or sound of } \\
\text { forest }\end{array}$ & $\begin{array}{l}\text { 1. Loud and noisy/full diversity of sounds } \\
\text { 2. Still lively and active but less forceful } \\
\text { 3. Muffled/quiet/little sound } \\
\text { 4. Dead silent/no noise } \\
\text { 5. Unknown }\end{array}$ \\
\hline & $\begin{array}{l}\text { The abundance of saplings in } \\
\text { the forest }\end{array}$ & $\begin{array}{l}\text { 1. A lot/crowded/dense thickets } \\
\text { 2. Plentiful/heaps/quite a few } \\
\text { 3. Not many/sparse/scattered/isolated poles/nothing } \\
\text { (Kore) } \\
\text { 4. Absolutely nothing (Tino kore nei) } \\
\text { 5. Unknown }\end{array}$ \\
\hline
\end{tabular}


Table 3 continued

\begin{tabular}{lll}
\hline $\begin{array}{l}\text { Culturally- } \\
\text { relevant themes }\end{array}$ & Indicators (Ngā pae tata) & Metrics for assessing indicators
\end{tabular}

(Pae tukutuku)

The abundance of seedlings in the forest

The amount of vegetation browse and damage (by deer and livestock) in the forest

The amount of possum sign (possum dung, bite marks and scratchings on trees) in the forest

Amount of vegetation cover (e.g., ferns, seedlings) on the forest floor

Strength and presence of the life essence or life-force within the forest

dimension (Taha wairua) (mauri)

Strength and presence of the energy flow or natural current in the forest (ia)
1. A lot/crowded/carpet of seedlings

2. Plentiful/heaps/common

3. Not many/sparse/scattered/isolated plants/ nothing (Kore)

4. Absolutely nothing (Tino kore nei)/forest floor bare

5. Unknown

1. Forest understory thick and impenetrable/ no damage or browse

2. Forest understory dense in places/quite thick/some browse and damage

3. Forest understory sparse/quite a bit of damage/vegetation trampled

4. Forest understory bare and eaten out/ vegetation absent/easy to walk through

5. Unknown

1. A lot

2. Common/quite a bit

3. Nothing (Kore)/not much

4. Absolutely nothing (Tino kore nei)

5. Unknown

1. Carpet of vegetation/wide range of species present/thick and luxurious/soft underfoot/ little leaf litter exposed

2. Pretty good vegetation cover/reasonable range of species present/ground still soft underfoot in places/patches of leaf litter

3. Not much vegetation cover/few different species present/ground feels firmer/much leaf litter covering large areas

4. Forest floor bare and open/ground feels hard and compact/leaf litter covering all of forest floor

5. Unknown

1. Active and flourishing/alive/healthy

2. Persists/still present but waning

3. Diminished/reduced capacity

4. Sleeping/dormant/hidden

5. Unknown

1. Over-whelmed and frightened/chilling or powerful force

2. Strong feeling or vibes

3. Less intense feeling or vibes

4. Diminished feeling but still present (Kare e rongo $\mathrm{i}$ te ihiihi)

5. Absent

6. Unknown 


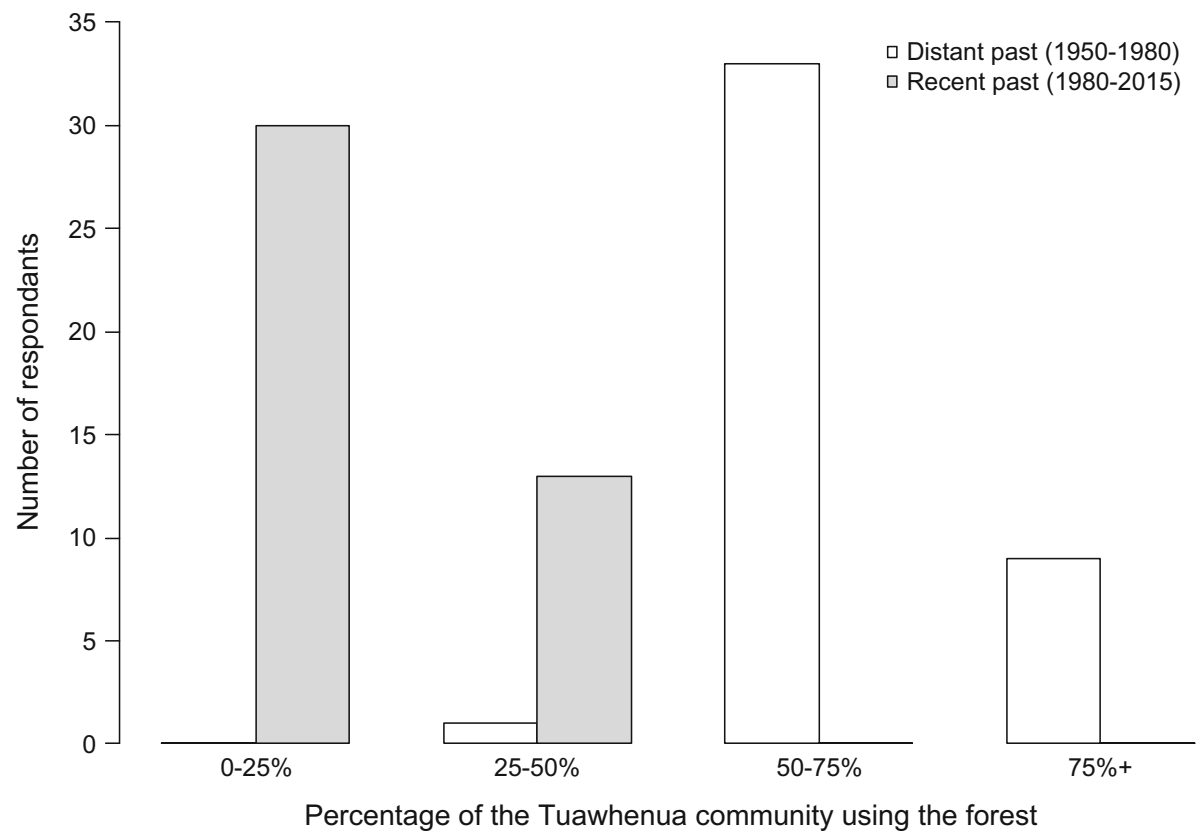

Fig. 2 Percentage of people in the Ruatāhuna community using the forest in the distant (1945-1980) and recent (1981-2015) past, based on a survey of 43 individuals over the age of 55 years

provide' for the community whether from native or introduced species (Table 2, food procurement). While the composition of foods sourced from the forest by Māori has changed over time, the process of hunting and collecting food is still an important part of the Tuawhenua lifestyle and relationship with the forest. In particular, the extinction of some native bird species (e.g., little bush moa, Anomalopteryx didiformis) and the large declines in the abundances of others (e.g., kākā, kererū, kōkō, and pihipihi) have meant that exotic ungulates (e.g., feral pig and red deer) have become an increasingly prominent form of forest-sourced protein. Fur from the exotic Australian brushtail possum has also been an important source of income for many community members (Jones et al. 2012). As a consequence, a number of indicators were associated directly (e.g., herd size, fat content, colour, texture or taste) or indirectly (e.g., tracking, browse damage, animal behaviour) with the hunting of these exotic ungulates and possums (Table 2). The forest also is still an important source of products for traditional medicinal purposes, ceremonial clothing fibre, and timber for traditional carving, construction materials and firewood. The quality and ease with which these materials could be obtained were used as indicators of forest health and well-being (Table 2). However, a potential issue with integrating resource use indicators into a monitoring system is the relationship between the harvest-based indicator and the total abundance of species. Harvesters can adjust their practices (e.g., increased harvest effort) in a variety of ways that can influence the shape of a harvest rate-abundance relationship. Small declines in harvest rates have the potential to hide larger declines in the population (Moller et al. 2004), therefore issues like this would need to be recognised and addressed within any community-based system. 
Indicators based on experiences and observations made while people travelled across the landscape and that were not related directly to the acquisition of resources (e.g., observations of indicators relating to land erosion, forest colour, configuration and structure, and local climate effects) were also common. These indicators often reflected the ease with which an individual could move across the landscape (e.g., sapling density, openness of forest, visibility of tree trunks). Observations relating to the presence of a species for the first time or changes in the distribution of species were also easily detected and interpreted by individuals. To comprehend and gauge how these indicators changed, however, required regular forays into the forest and past knowledge of species abundance, condition or distributions. It was also common for two or more related indicators to be considered simultaneously, such as those that informed on the openness of the forest and its capacity to act as a regulator of erosion and water quality (Table 2, nature of the forest-field survey). Multiple indicators were also used as proxies for other forest events or processes such as fruiting. The abundance, colour and flavour of fat on harvested feral pigs were used to gauge the intensity and quality of a fruiting on trees like the tawa and hīnau. This multiindicator based approach allows forest users to cross-check their understandings of forest structure and processes (see Table 2, food procurement-interview-based). In contrast, New Zealand's national biodiversity monitoring and reporting system uses predominantly visual measurements of biodiversity, with an exception of five-minute bird counts which include an auditory measure.

Community and human-biodiversity relations based on reciprocal exchange are fundamental ontological principles for indigenous peoples and hunting cultures around the world (Kendrick et al. 2005; Nadasdy 2007; Sangha et al. 2011). Indicators of these relationships were important for the Tuawhenua people. Tuawhenua recognised that the health of the forest ecosystem was linked integrally to the community's fundamental principles of environmental guardianship or stewardship (kaitiakitanga), practice of caring for visitors (manaakitanga), and interrelatedness within natural and spiritual worlds (whakawhanaungatanga). The strength of community spirit and commitment to others (matemateone) was viewed as an indicator that measured the extent to which these principles were observed and practised. Sharing of resources has traditionally reinforced relationships and community unity. However, declines in forest resources and their use, combined with a greater reliance on store-bought foods and a monetised economy, have eroded the behaviours that contributed to the strength and integrity of this indicator.

\section{Contributions to a community-based monitoring system}

This study has taken the initial steps towards developing a forest monitoring system with indicators that are relevant and make sense to a Māori community. Indicators identified in this study were methods that the Tuawhenua community understood, trusted and felt informed them about the state of their forest and community. The ongoing utility of these culturally-based cues is highly dependent on regular use of the forest by community members to form, validate and update their impressions of forest health and well-being. Indicators need to inform on ecosystem structure and state, but also the health of humanenvironment relationship. Interviewees in this study identified clearly that forests and people were interconnected tightly and that their forest had become 'lonely' since fewer community members were now venturing into it. The lack of people on the land meant the feeling of loneliness and isolation was felt closer and closer to the community over the years. In an effort to reverse this trend, Tūhoe aim to resettle historic village sites within the region that was once Te Urewera National Park (Lyver et al. 2014). This approach is in 
stark contrast to those individuals within New Zealand who advocate for 'wilderness' values that exclude humans from the environment to be recognised in legislation (Abbott and Reeve 2011).

The dual application of both field survey and interview-based indicators is likely to be the most effective approach for understanding socio-ecological health and integrity. The declining use of the forest by the Tuawhenua community over the past three decades (Fig. 2) will have affected the frequency with which individuals observe indicators and therefore form impressions and report on status and change. This declining frequency in forest use has ramifications for the type of monitoring approach that is applied. The temporal and spatial comparative nature of the interview-based approach relies heavily on regular and repeated forest visits and/or harvest of resources to form and update impressions of forest state during a season or over multiple years. Commonly, impressions of an indicator would be formed either directly through the harvest of a resource, or gleaned as an individual travelled on the land and made general observations. Replication of activities at different temporal and spatial scales allowed members from the Tuawhenua community to build on and constantly cross-check the accuracy of their observations. With a much smaller proportion of the community now using the forest on a regular basis, the interviewbased approach would rely on the observations of only a small group of individuals. However, the field survey approach only utilized indicators from five of nine culturallyrelevant themes identified. Using both monitoring approaches would therefore, utilize indicators from the full suite of themes allowing full assessment of forest and community health.

A field survey approach provides an assessment at a fixed point in time, although the impressions formed of the forest by forest users is highly likely to incorporate their prior experience and knowledge of past forest health. The assessment of an indicator will therefore sit on a continuum depending on how an individual perceives or gauges the indicator (e.g., none, few, some and a lot) in relation to the past. As with any primarily subjective indicator, there is likely to be marked individual heterogeneity depending on individuals' age, experience and frequency of forest use. For example, community elders who have seen the large flocks of kererū (200-300 birds) in the past might grade a flock of 30 kererū quite differently to a younger community member who has only experienced kererū populations in their depleted state and therefore would consider 30 birds to be a large flock. This "shifting baseline" (Pauly 1995) or "ecological amnesia" (Seidensticker 2008) is a characteristic feature of community-based monitoring systems where populations or ecosystems are changing over generational timeframes. It is also an issue for scientific quantitative monitoring systems which might lack historical monitoring records and can only report on population and ecosystem states 'as of now'. In part, this reflects the imperative for measures to reflect the outcomes of current management responses such as pest control. However, an alignment of quantitative measures with indicator gradients as understood by elders within a community as part of an assessment would provide context in which to view the current state of an ecosystem, support cross-generational consistency, and enhance the interpretation of results. It would help minimise the shifting ecological baseline effect.

The application of a field survey platform as a means to monitor the state of the environment raises issues around how environmental information is collected and processed by IPLCs. The field survey approach can be likened to the scientific system of monitoring biodiversity where measures are obtained at fixed points in time using a repeatable survey method. Traditional methods of knowing presented in this study did not evolve as indicators to be applied within a survey protocol and it therefore could be argued 
that it is inappropriate to try. On the other hand, if community members are no longer entering the forest in the same numbers, or as often, or for as long, then a field survey survey-based approach using indicators deemed relevant by the community can be both informative and useful. Not all indicators, however, lend themselves to a field survey approach, which further supports the case for applying a dual field survey and interviewbased monitoring approach (e.g., see approaches for monitoring barren-ground caribou, Rangifer tarandus groenlandicus; Lyver and Łútsël K'é Dëne First Nation 2005).

\section{Challenges confronting community-based monitoring systems}

Monitoring is an increasingly essential condition of co-management as government authorities require routine performance reporting and an evidential basis for management outcomes (McNie 2007). Indigenous peoples typically 'manage' and 'monitor' at a localised or catchment scale reflecting community values and priorities. This challenges the ability to scale-up indicators across multiple communities and landscapes and to make inferences about the national state of biological and community well-being. Unlike a science-based monitoring system, there is likely to be greater diversity in communitybased indicators between different regions of a country. This makes it difficult to compare data and interpretations of the state of biodiversity. While it is likely that congruencies in indicators will exist across communities and areas, with relatively few adaptions required for wider application, others will be site-specific and will be applied and interpreted in slightly different ways. The challenge confronting practitioners, therefore, will be to balance the variability that emerges from engaging different spatially-specific indicators and the comparativeness of indicators across multiple communities with the informative value of resulting aggregated indicators for assessing the national state of the environment and/or the community's relationship with it.

The contribution of indigenous community-based monitoring systems to regional and national efforts to monitor state of biodiversity needs consideration. For countries like New Zealand, where approaches such as the National Biodiversity Monitoring and Reporting System (Lee et al. 2005; Ministry for the Environment and Statistics New Zealand 2015a) have been developed, alignment of the different monitoring approaches would enrich the knowledge about the state of the environment and contribute a broader understanding of the relationships communities hold with their biodiversity. For example, in the Kalahari, Botswana, participatory and ecological methods were combined to develop indicators to monitor the sustainability of land management (Reed et al. 2008). The variety of indicators and the methods used should add scope, rigour, and resilience to the current approach rather than raising obstacles (e.g., Huntington 2000; Reed et al. 2008; Danielsen et al. 2014b).

\section{Conclusion}

Changes to lifestyles and biodiversity can alter how indigenous communities use, understand and relate to indicators that reflect their environments. Regardless of the circumstances however, the indicators used within a community-based monitoring process need to be relevant and trusted by the people whom they are intended to serve. Decisions about which indicators to implement should also be made in relation to clearly defined objectives that allow performance to be gauged in a meaningful and timely manner (Lindenmayer et al. 2012). Since values or priorities for communities are often best expressed in their 
resource use practices, the ideal monitoring system is one where community members can report on biodiversity based on their 'undisturbed' routines. However, in situations where there is reduced resource use or movement on the land by the community (such as in this study), a field survey approach using indicators identified by community elders or experts might offer an alternative method for monitoring environmental health. Such an approach would require elders or experts to go out on their lands specifically for the purpose of providing their impressions of biodiversity. An alternate method might involve members of the community being trained by their elders and/or resource users to recognise and measure indicators in their different states using prescribed metrics. Impressions of indicators that are formed over longer timeframes could then be sourced using an interview-based approach. This method would also allow qualitative indicators related to the forest-community relationship to be included in assessments. A field survey approach is inherently more expensive than an interview-based approach which draws its information from existing forest use. However, if elders are engaged in the field survey, forests can be measured against past ecological baselines or health that elders recall from their youth. A qualitative field survey approach also offers opportunities to cross-check how some congruent indicators align quantitative scientific monitoring data. The application of an indigenous community-based monitoring system in conjunction with a scientific-based approach therefore is likely to be highly informative over time. It also gives indigenous communities an important stake in the interpretation and decision-making processes, ensuring that biodiversity and cultural values relevant to their people are protected and maintained.

Acknowledgments We thank the interviewees and workshop participants that contributed to this study. Moehau Kutia, Te Peeti (Spady) Kutia, Te Motoi Taputu, Tangiora Tawhara, June Tihi, and Kirituia Tumarae-Teka contributed to the collection, translation and transcription of interviews. Anne Sutherland constructed our location map. The study was conducted under the directorship of the Tūhoe Tuawhenua Trust and was funded by MBIE Grants (C09X0308; C09X1307) and Crown Research Institute 'Māori and Biodiversity' Core funding. Thanks to the editor and three anonymous referees for their review of this article.

Open Access This article is distributed under the terms of the Creative Commons Attribution 4.0 International License (http://creativecommons.org/licenses/by/4.0/), which permits unrestricted use, distribution, and reproduction in any medium, provided you give appropriate credit to the original author(s) and the source, provide a link to the Creative Commons license, and indicate if changes were made.

\section{Glossary of Māori words and terms}

Ahikaaroa

Āhua

$\bar{A}$ hua o te ngahere

Āhua o te wai

Āhua o te whenua

Anuanu

Hapū

Harore

Hahuru

Hīnau

Hua o te whenua
Long burning fires associated with the continual occupation of land and place; title to land through occupation

Nature, character, qualities

Nature of the forest

Nature of the water

Nature of the land

Offensive or ugly

Sub-tribes

Fungi, Armillaria novaezelandiae

Thunderous

Elaeocarpus dentatus

Natural productivity or fat of the land 
Ia

Ihi

Kaitiakitanga

Kākā

Kākāriki

Karakia

Kāramuramu

Kare i rahi

Kererū

Kiwi

Kōkō

Koparapara

Kore

Korowai

Kōura

Mahinga kai

Makuru

Manaakitanga

Mana

Manomano

Māori

Marae

Māramatanga

Mātauranga

Matemateone

Matomato

Mauku

Mauri

Mokemoke

Mōteatea

Ngā pae o te

mātauranga

Ngā pae tata

Ngā pae tawhiti

Pae tukutuku

Patupaiarehe

Pepeketua/poroka

Pihipihi

Pikopiko

Puha

Pūtangitangi

Raumahehe
Flow of energy

Essential force, charm, power, personal magnetism, dread, fear and a response of awe or unexplained phenomena

Practice of guardianship or stewardship over natural resources New Zealand bush parrot, Nestor meridionalis

New Zealand parakeet, Cyanoramphus spp

Prayer or incantation

Coprosma lucida

Hardly any

New Zealand wood pigeon, Hemiphaga novaeseelandiae novaeseelandiae

North Island brown kiwi, Apteryx mantelli

Tūî, Prosthemadera novaeseelandiae

Bellbird, Anthornis melanura

Nothing

Cloak

North Island freshwater crayfish, Paranephrops planifrons

Food and processes for its procurement

Everywhere

Practice of caring for people

Accorded authority and respect

Plentiful

Indigenous people of New Zealand

Traditional meeting places

Wisdom

Māori knowledge

Feeling and practice of engendering community spirit and caring

A lot

Plant and leaves of the hen and chicken fern, Asplenium bulbiferum

Life force, life essence

Lonely

Songs sung in traditional mode

Monitoring approaches

Survey-based monitoring approach; horizon or platform for short-term indicators monitoring assessment

Interview-based monitoring approach; horizon or platform for long-term indicators monitoring assessment

Culturally-relevant themes

Forest dwelling supernatural beings

Native frog, Leiopelma hochstetteri

Silver-eye, Zosterops lateralis

New shoots of the hen and chicken fern, Asplenium bulbiferum

Sow thistle, Sonchus kirkii

Paradise shelduck, Tadorna variegata

Native freshwater fish (Galaxias spp.) 


$\begin{array}{ll}\text { Raranga } & \text { The practice of weaving } \\ \text { Rereke } & \text { Changed } \\ \text { Rongoā } & \text { Vegetation used within traditional medicines } \\ \text { Ruru } & \text { Morepork, Ninox novaeseelandiae } \\ \text { Taha wairua } & \text { Spiritual aspect or dimension } \\ \text { Tāmoko } & \text { Traditional forms of tattooing } \\ \text { Tāne [Mahuta] } & \text { God of the forest realm } \\ \text { Taha hinengaro } & \text { Mental aspect or dimension } \\ \text { Taha kikokiko } & \text { Physical aspect or dimension } \\ \text { Taniwha } & \text { Environmental guardian } \\ \text { Tapu } & \text { Sacred, prohibited, restricted, set apart, forbidden. Objects or } \\ & \text { people of great importance or functional significance can } \\ & \text { become tapu } \\ \text { Tawa } & \text { Beilschmiedia tawa } \\ \text { Tawhero } & \text { Weinmannia racemosa } \\ \text { Tikanga } & \text { Traditional customs and protocols } \\ \text { Tino kore nei } & \text { Absolutely nothing } \\ \text { Tī kouka } & \text { Cabbage tree, Cordyline australis } \\ \text { Toromiro } & \text { Miro, Prumnopitys ferruginea } \\ \text { Tōtara } & \text { Podocarpus totara } \\ \text { Tuna } & \text { Freshwater longfin eel, Anguilla dieffenbachii } \\ \text { Tūrehu } & \text { Supernatural forest dwelling beings } \\ \text { Waiata } & \text { Song } \\ \text { Wairua } & \text { Spiritual dimension } \\ \text { Wana } & \text { Awesome power, inspiring, gusto } \\ \text { Whakairo } & \text { Wood carving in traditional styles } \\ \text { Whakawhanaungatanga } & \text { Inter-relationships or kinship with people and environment } \\ \text { Wehi } & \text { Inspirational power } \\ & \end{array}$

\section{References}

Abbott M, Reeve R (2011) Wild Heart. The possibility of wilderness in Aotearoa New Zealand. Otago University Press, Dunedin

Agrawal A (1995) Dismantling the divide between indigenous and scientific knowledge. Dev Change 26:413-439. doi:10.1111/j.1467-7660.1995.tb00560.x

Berkes F (2012) Sacred ecology, 3rd edn. Routledge, New York

Berkes F, Folke C (eds) (1998) Linking social and ecological systems: management practices and social mechanisms for building resilience. Cambridge University Press, Cambridge

Bohensky EL, Maru Y (2011) Indigenous knowledge, science, and resilience: what have we learned from a decade of international literature on "integration"? Ecol Soc 16(4):6. doi:10.5751/ES-04342-160406

Carswell FE, Richardson SJ, Doherty JE, Allen RB, Wiser SK (2007) Where do conifers regenerate after selective harvest? A case study from a New Zealand conifer-angiosperm forest. Forest Ecol Manag 253:138-147

Chapin FS, Carpenter SR, Kofinas GP, Folke C, Abel N, Clark WC, Olsson P, Smith DMS, Walker B, Young OR, Berkes F, Biggs R, Grove JM, Naylor RL, Pinkerton E, Steffen W, Swanson FJ (2010) Ecosystem stewardship: sustainability strategies for a rapidly changing planet. Trends Ecol Evol 25:241-249

Christensen RHB (2015) Ordinal—regression models for ordinal data. R package version 2015. 6-28. http:// www.cran.r-project.org/package=ordinal/ 
[CBD] Convention on Biological Diversity (2015) Article 8(j) - Traditional knowledge, innovations and practices. https://www.cbd.int/traditional/. Accessed 28 Oct 2015

Danielsen F, Jensen PM, Burgess ND, Altamirano R, Alviola PA, Andrianandrasana H, Brashares JS, Burton AC, Coronado I, Corpuz N, Enghoff M, Fjeldså J, Funder M, Holt S, Hübertz H, Jensen AE, Lewis R, Massao J, Mendoza MM, Ngaga Y, Pipper CB, Poulsen MK, Rueda RM, Sam MK, Skielboe T, Sørensen M, Young R (2014a) A multicountry assessment of tropical resource monitoring by local communities. Bioscience 64:236-251

Danielsen F, Jensen PM, Burgess ND, Coronado I, Holt S, Poulsen MK, Rueda RM, Skielboe T, Enghoff M, Hemmingsen LH, Sørensen M, Pirhofer-Walzl K (2014b) Testing focus groups as a tool for connecting indigenous and local knowledge on abundance of natural resources with science-based land management systems. Conserv Lett 7(4):380-389

Ens EJ, Pert P, Clarke PA, Budden M, Clubb L, Doran B, Douras C, Gaikwad J, Gott B, Leonard S, Locke J, Packer J, Turpin G, Wason S (2015) Indigenous biocultural knowledge in ecosystem science and management: review and insight from Australia. Biol Conserv 181:133-149

Harmsworth GR, Awatere S (2013) Indigenous Māori knowledge and perspectives of ecosystems. In: Dymond J (ed) Ecosystem services in New Zealand: conditions and trends. Manaaki Whenua Press, Landcare Research, Palmerston North, pp 274-286

Huntington HP (2000) Using traditional ecological knowledge in science methods and applications. Ecol Appl 10:1270-1274

IPBES (Intergovernmental Science-Policy Platform on Biodiversity and Ecosystem Services) (2013) Report of the international expert workshop on the contribution of indigenous and local knowledge systems to the Platform. Bonn, Germany, Intergovernmental Science-Policy Platform on Biodiversity and Ecosystem Services. Document IPBES/2/INF/1

IPBES (Intergovernmental Science-Policy Platform on Biodiversity and Ecosystem Services) (2016) Update on the work of the task force on indigenous and local knowledge systems (deliverable 1 (c)). Work programme of the Platform: work on indigenous and local knowledge systems. Bonn, Germany, Intergovernmental Science-Policy Platform on Biodiversity and Ecosystem Services. Document IPBES/4/INF/6

Jollands N, Harmsworth H (2007) Participation of indigenous groups in sustainable development monitoring: rationale and examples from New Zealand. Ecol Econ 62:716-726

Jones C, Barron M, Warburton B, Coleman M, Lyver PO'B, Nugent G (2012) Serving two masters: reconciling economic and biodiversity outcomes of brushtail possum (Trichosurus vulpecula) fur harvest in an indigenous New Zealand forest. Biol Conserv 153:143-152

Kendrick A, Lyver PO'B, Łútsël K'é Dëne First Nation (2005) Denesoline (Chipewyan) knowledge of barren ground caribou (Rangifer tarandus groenlandicus) movements. Arctic 58:175-191

King CM (1990) The handbook of New Zealand mammals. Oxford University Press, Oxford

Lee W, McGlone M, Wright E (2005) Biodiversity inventory and monitoring: A review of national and international systems and a proposed framework for future biodiversity monitoring by the Department of Conservation. Landcare Research, Lincoln

Lindenmayer DB, Gibbons P, Bourke M, Burgman M, Dickman CR, Ferrier S, Fitzsimons J, Freudenberger D, Garnett ST, Groves C, Hobbs RJ, Kingsford RT, Krebs C, Legge S, Lowe AJ, McLean R, Montambault J, Possingham H, Radford J, Robinson D, Smallbone L, Thomas D, Varcoe T, Vardon M, Wardle G, Woinarski J, Zerger A (2012) Improving biodiversity monitoring. Austral Ecol 37:285-294

Lyver PO'B, Łútsël K'é Dëne First Nation (2005) Monitoring barren-ground caribou body condition with Denesoline traditional knowledge. Arctic 58:44-54

Lyver PO'B, Taputu M, Kutia ST, Tahi B (2008) Tūhoe Tuawhenua mātauranga of kererū (Hemiphaga novaseelandiae novaseelandiae) in Te Urewera. N Z J Ecol 32:7-17

Lyver PO'B, Jones C, Doherty J (2009) Flavour or fore-thought: Tūhoe traditional management strategies for the conservation of kererū (Hemiphaga novaeseelandiae novaeseelandiae) in New Zealand. Ecol Soc 14(1). http://www.ecologyandsociety.org/vol14/iss1/art40/

Lyver PO'B, Davies J, Allen R (2014) Settling indigenous claims to protected areas: weighing Māori aspirations against Australian experiences. Conserv Soc 12(1):89-106

MacLeod CJ, Affeld K, Allen RB, Bellingham PJ, Forsyth DM, Gormley AM, Holdaway RJ, Richardson SJ, Wiser SK (2012) Department of Conservation biodiversity indicators: 2012 assessment. Landcare Research, Lincoln

McNie E (2007) Reconciling the supply of scientific information with user demands: an analysis of the problem and review of the literature. Environ Sci Policy 10:17-38

Ministry for the Environment, Statistics New Zealand (2015a) Environment Aotearoa 2015. Ministry for the Environment, Statistics New Zealand, Wellington, New Zealand. http://www.mfe.govt.nz/publications/ environmental-reporting/environment-aotearoa-2015 
Ministry for the Environment, Statistics New Zealand (2015b) Topics for environmental reporting-consultation document. Ministry for the Environment, Statistics New Zealand, Wellington, New Zealand. http://www.mfe.govt.nz/publications/environmental-reporting/topics-environmental-reporting-consultationdocument

Moller H, Berkes F, Lyver PO'B, Kislalioglu M (2004) Combining science and traditional ecological knowledge: monitoring populations for co-management. Ecol Soc 9(3): 2. http://www.ecologyands ociety.org/vol9/iss3/art2

Moller H, Lyver PO'B, Bragg C, Newman J, Clucas R, Fletcher D, Kitson J, McKechnie S, Scott D Rakiura Tî̀tī Islands Administering Body (2009) Guidelines for cross-cultural participatory action research partnerships: a case study of a customary seabird harvest in New Zealand. N Z J Zool 36:211-241

Morunga K, Tahi B (2013) Industry and people: development in the Tuawhenua. Tūhoe Tuawhenua Trust, Ruatāhuna

Nadasdy P (1999) The politics of TEK: power and the "integration" of knowledge. Arct Anthropol 36:1-18

Nadasdy P (2007) The gift in the animal: the ontology of hunting and human-animal sociality. Am Ethnol 34:25-43

New Zealand Government (1987) Conservation Act 1987. Public Act-NZ legislation. New Zealand Government, Wellington

Nikora LW, Guerin B, Rua M, Te Awekotuku N (2004) Moving away from home: some social consequences for Tuhoe migrating to the Waikato. N Z Popul Rev 30(1/2):95-112

Pauly D (1995) Anecdotes and the shifting baseline syndrome of fisheries. Tree 10:30

Reed M, Dougill AJ, Baker TR (2008) Participatory indicator development: what can ecologists and local communities learn from each other? Ecol Appl 18(5):1253-1269

Sangha KK, Butler JRA, Delisle A, Stanley O (2011) Identifying links between ecosystem services and Aboriginal well-being and livelihoods in north Australia: applying the millennium ecosystem assessment framework. J Environ Sci Eng 5:931-946

Seidensticker J (2008) Ecological and intellectual baselines: saving lions, tigers, and rhinos in Asia. In: Rockwood L, Stewart R, Dietz T (eds) Foundations of environmental sustainability: the coevolution of science and policy. Oxford University Press, New York

Shiel D, Boissiere M, Beaudoin G (2015) Unseen sentinels: local monitoring and control in conservation's blind spots. Ecol Soc 20(2):39. doi:10.5751/ES-07625-200239

Sobrevila C (2008) The role of indigenous peoples in biodiversity conservation. World Bank, Washington, DC

Statistics New Zealand (2013) 2013 Census quickstats about Māori. New Zealand Government, Wellington, New Zealand. http://www.stats.govt.nz/Census/2013-census/profile-and-summary-reports/quickstatsabout-maori-english/population.aspx

Stephenson J, Berkes F, Turner NJ, Dick J (2014) Biocultural conservation of marine ecosystems: examples from New Zealand and Canada. Indian J Tradit Knowl 13:257-265

Tengö M, Brondizio ES, Elmqvist T, Malmer P, Spierenburg M (2014) Connecting diverse knowledge systems for enhanced ecosystem governance: the multiple evidence base approach. Ambio 43:579-591

Tennyson A, Martinson P (2006) Extinct birds of New Zealand. Te Papa Press, Wellington

Thaman R, Lyver PO’B, Mpande R, Perez E, Cariño J, Takeuchi K (eds) (2013) The contribution of indigenous and local knowledge systems to IPBES: building synergies with science. IPBES Expert Meeting Report, UNESCO/UNU. UNESCO, Paris

Tipa G, Teirney L (2006) A cultural health index for streams and waterways: a tool for nationwide use. Ministry for the Environment, Wellington

UNEP (United Nations Environment Programme) (2012) Consideration of initial elements: recognizing indigenous and local knowledge and building synergies with science. IPBES/1/INF/5. http://www. ipbes.net/plenary/ipbes-1.html

Wehi PM (2009) Indigenous ancestral sayings contribute to modern conservation partnerships: examples using Phormium tenax. Ecol Appl 19(1):267-275

Wilmshurst JM, Moar NT, Wood JR, Bellingham PJ, Findlater AM, Robinson JJ, Stone C (2014) Use of pollen and ancient DNA as conservation baselines for offshore islands in New Zealand. Conserv Biol 28:202-212 